\title{
Watershed management for sustainable water supply and food security
}

\section{Editorial}

Watershed Management has to be a prime activity in highpopulation, low-income developing countries so as to achieve foodsecurity and safe quality drinking water supply for their growing population. This is because the changes in climatic pattern due to global warming have resulted in erratic rainfall, high-intensity storms and flash floods with prolonged dry period's in-between. Such rainfall pattern is harmful for rain-fed crops on which majority of the farmers in low-income countries depend for their livelihood.

In order to generate dependable water resources from such a harsh climate, we need a shock-absorbing, resilient interface between the climate and the surface water and ground water resources. This interface could only be provided by well-maintained and well forested watersheds, starting from the watershed of a 'first-order' stream. This is achieved through maintaining a good cover of grasses, bushes and trees; protecting the soil with contour bunding and contour tilling of farms; excavating farm-ponds for temporary storage of rain water; de-silting of small ponds and lakes; and constructing bunds and underground bunds across small streams for water storages to promote recharge to ground water. These are the actions at field level which should start in the watershed of a first order stream and progressively cover larger watersheds, with active participation of villagers under guidance from NGOs and government departments.

The above actions comprise the 'bottom-up' contribution to IWRM by farmers and villagers at the grass-root level, but must still be complimented by 'top-down' efforts provided by governments and international organizations through the provision of funds, infrastructure development, a legislative framework and promoting the role NGOs as a liaison between the Government schemes, Government Officers and village communities. In line with the prescriptions of Agenda 21 and the SDGs (Sustainable Development Goals), NGOs should also encourage the active participation of women in the forestation of watersheds and in drinking water supply schemes.

To start these actions at watershed level, rural communities and their elected village councils have to liaise with district or county level development offices in the appropriate Government Departments. Watershed improvements through soil and water conservation activities and forestation could go a long way to assure at least one crop during rainy season and sustainable ground water supply for small scale irrigation in other seasons. Watershed development is the surest way to stabilize rural communities through both food and water
Volume 3 Issue I - 2019

\author{
Shrikant Daji Limaye \\ Director of Ground Water Institute (NGO), Based in Pune, \\ India
}

Correspondence: Shrikant Daji Limaye, Director of Ground Water Institute (NGO), Based in Pune, India, Email limaye@vsnl.com

Received: December II, 2018 | Published: January 08, 2019

security at village level and reduce the exodus of rural populations to nearby cities. Such 'drought-induced urbanization' is putting severe pressure on the infrastructural facilities of already over-crowded cities.

Watershed development will not just enable farmers to produce more food and to get access to potable drinking water; it could also provide local employment to landless labours. Through watershed programmes, the total biomass output of the watershed increases, resulting in both a better environment and increased income. Many rural communities produce 'value added' products from agrooutput and dairy. Safe drinking water obtained from bore wells could drastically improve rural health and therefore also economic productivity. There is a thus a clear positive impact on 'income of rural families' from effective local watershed development schemes at village level.

So, we have to move from analysis at conferences to actions at the grass-root level. The Road Map is: Watershed development, Soil and water conservation activities, Forestation of barren hills with local grasses, bushes and trees, providing facilities for Agro-inputs such as seeds, fertilizers etc.; providing storage and marketing facilities for Agro-outputs, Promotion of agro-industries; providing drinking water bore-wells for safe quality drinking water. In order to initiate actions at grass-root level it is necessary for Hydrologists to observe "SocioHydrology" (SH) or "Taking the Science of Hydrology to the Society" as per the directive of UNESCO's Water Division and educate the rural population.

\section{Acknowledgment}

None.

\section{Conflicts of interest}

The author declares that there is no conflict of interest. 